\title{
Perumusan Strategi Bersaing pada Perusahaan Ban dengan Metode Analisis Portofolio Produk (Studi Kasus: PT Multistrada Arah Sarana, Tbk)
}

\author{
Nathanael August Zefanya, Bustanul Arifin Noer, dan Muhammad Saiful Hakim \\ Jurusan Manajemen Bisnis, Fakultas Teknologi Industri, Institut Teknologi Sepuluh Nopember (ITS) \\ Jl. Arief Rahman Hakim, Surabaya 60111 Indonesia \\ e-mail: bus4arifin@gmail.com
}

\begin{abstract}
Abstrak-Industri ban di Indonesia mengalami perkembangan pesat dalam kurun waktu 10 tahun terakhir. Terjadinya peningkatan permintaan baik dari masyarakat lokal maupun luar negeri membuat setiap produsen ban asal Indonesia untuk berlomba-lomba mengembangkan produk bannya dalam meraih pangsa pasar yang ada. Namun, terjadinya krisis ekonomi global menjadi penyebab menurunnya pendapatan dan angka penjualan yang mempengaruhi keberlangsungan bisnis dari produsen ban di Indonesia, salah satunya adalah PT MASA dengan produk utamanya yaitu ban mobil dengan merek Achilles dan ban motor dengan merek Corsa yang digunakan sebagai objek penelitian ini. Untuk menjawab permasalahan yang ada, dilakukan analisis industri dengan analisis PESTEL dan Porter's Five Forces, identifikasi faktor lingkungan internal dan eksternal dengan analisis SWOT serta merumuskan alternatif strategi bersaing untuk direkomendasikan kepada PT MASA. Perumusan strategi alternatif didapat dari hasil analisis Matriks BCG (Boston Consulting Group) dan Matriks IE (Internal-Eksternal) sebagai analisis portofolio produk untuk mendapatkan tema strategi alternatif dalam pembuatan Matriks SWOT. Strategi alternatif kemudian diperingkatkan dengan metode QSPM (Quantitative Strategic Planning Matrix) dan dilanjutkan dengan pembuatan rencana aksi bagi PT MASA dalam jangka waktu 5 tahun ke depan.Setelah dilakukan analisis industri, diketahui bahwa ancaman terbesar datang dari pesaing produsen ban. Dari hasil analisis portofolio, PT MASA berada di kuadran I karena memiliki koordinat IFE (Internal Factor Evaluation) serta EFE (External Factor Evaluation) masing-masing 3,32 dan 3,26. Dari hasil analisis Matriks Internal-Eksternal (Matriks IE), PT MASA direkomendasikan untuk melakukan strategi grow and build. Hasil Matriks BCG menunjukkan bahwa Achilles berada di kuadran dogs, sementara Corsa berada di kuadran question marks. Terdapat 13 strategi alternatif hasil dari formulasi strategi dengan menggunakan matriks TOWS. Dari hasil analisis QSPM, terdapat 7 alternatif strategi terbaik dan rencana aksi untuk direkomendasikan kepada PT MASA.
\end{abstract}

Kata Kunci- Industri Ban, Matriks BCG, Matriks IE, Perumusan Strategi, QSPM

\section{PENDAHULUAN}

Salah satu industri yang memiliki potensi dan perkembangan yang pesat adalah industri ban. Pada tahun 2013, Industri ban nasional mengalami peningkatan penjualan ban sebesar 5 persen dari 96,57 juta unit ban pada tahun 2012 menjadi 101,43 juta unit ban (APBI, 2013) ${ }^{[1]}$. Angka tersebut didapat dari hasil penjualan ban mobil yang mencapai 47,26 juta unit ban serta penjualan ban motor yang mencapai 54,16 juta unit ban [1].

Penjualan ban sangat berkaitan dengan industri otomotif. Pada tahun 2013, terjadi peningkatan penjualan sebesar 10,2\% menjadi 1,4 juta unit mobil dari tahun sebelumnya. Sementara itu,di tahun yang sama tercatat total penjualan ban motor sebesar 54,16 juta unit ban di mana angka tersebut meningkat sebesar 16,4\% dari total penjualan pada tahun 2012 yaitu 47,04 juta unit ban [1].

PT MASA merupakan sebuah produsen ban di Indonesia yang telah berdiri sejak tahun 1988. Produk yang dihasilkan oleh PT MASA adalah ban luar dengan merek dagang Achilles untuk ban mobil dan merek Corsa untuk ban motor. Walaupun terdapat perubahan trend penggunaan kendaraan bermotor dalam beberapa tahun terakhir, PT MASA terus mengalami penurunan pendapatan sejak tahun 2011 yang disebabkan oleh krisis ekonomi global dan menurunnya permintaan baik dari pasar domestik maupun ekspor. Dampak dari penurunan tersebut sangat mempengaruhi PT MASA karena 80 persen penjualan produk dilakukan secara ekspor. Penurunan penjualan bersih juga disebabkan oleh penjualan ban Achilles dan Corsa yang cenderung fluktuatif. Adanya peningkatan penjualan ban motor pada tahun 2015 menjadi 3,30 juta unit ban tidak dapat menambah penjualan bersih PT MASA pada tahun tersebut karena terdapat penurunan yang cukup besar dari penjualan ban Achilles, yaitu dari 7,74 juta unit ban menjadi 6,82 juta unit ban [2].

Untuk dapat terus tersaing dalam industri ban yang semakin ketat, setiap perusahaan harus mempersiapkan diri dengan strategi-strategi bisnis. Menurut [3], strategi adalah arahan jangka panjang suatu perusahaan atau organisasi dalam meraih keunggulan melalui pemanfaatan sumber daya alam dan lingkungan yang dinamis guna memenuhi kebutuhan pasar harapan para stakeholder.

Menurut [4], perusahaan harus melihat kondisi industri ban dengan memperhatikan ancaman yang ada dari pihak kompetitor, barang substitusi, pendatang baru, serta memperhatikan daya tawar pemasok dan pembeli. Analisis industri juga dilakukan dengan metode analisis PESTEL (Politik, Ekonomi, Sosio-kultural, Teknologi, Legal, Ekologi) untuk melihat kondisi eksternal yang dapat mempengaruhi keberlangsungan bisnis suatu perusahaan. Dari sisi internal, akan dilakukan pendekatan berupa pembuatan bisnis model yaitu BMC (Business Model Canvas) untuk memperlihatkan 
alur dan struktur bisnis suatu perusahaan [5]. Pembuatan strategi pada penelitian ini menggunakan model strategi formulasi dari Fred David dimana terdapat tiga tahap, yaitu tahap input, tahap pencocokan dan tahap pengambilan keputusan [6].

Berbagai faktor internal dan eksternal yang diidentifikasi tersebut kemudian akan diberi pembobotan untuk dipetakan pada Matriks Evaluasi Faktor Internal (Matriks EFI) dan Matriks Evaluasi Faktor Eksternal (Matriks EFE) sebagai tahap input. Nilai pembobotan tersebut akan menunjukkan posisi perusahaan dari faktor-faktor yang telah diidentifikasi. Kedua matriks di atas akan menjadi bahan pembuatan matriks Matriks Internal-Eksternal (Matriks IE). Matriks IE dibuat untuk memetakan posisi PT MASA baik secara internal maupun eksternal perusahaan. Selain Matriks IE, matriks yang digunakan dalam penelitian ini adalah Matriks BCG (Boston Consulting Group). Matriks BCG dibuat untuk menunjukkan pangsa pasar relatif dan tingkat pertumbuhan dari masingmasing kategori produk ban yang akan diteliti. Kedua matriks tersebut merupakan matriks portofolio yang digunakan untuk analisis portofolio produk PT MASA pada tahap pencocokan.

Hasil analisis Matriks IE dan Matriks BCG kemudian akan digunakan sebagai tema utama dalam perumusan strategi alternatif. Strategi alternatif akan dijabarkan menggunakan Matriks SWOT (strengths, weaknesses, opportunities, threats). Strategi alternatif yang telah dirumuskan kemudian akan diberi penilaian dan prioritas dengan Quantitative Strategic Planning Matrix (QSPM). QSPM tersebut merupakan alat untuk melakukan pemilihan strategi alternatif terbaik dan menjadi metode yang digunakan untuk tahap pengambilan keputusan. QSPM tersebut akan menjadi bahan pembuatan rencana aksi bagi PT MASA.

Penelitian ini dilakukan pada PT MASA untuk menganalisis kondisi industri ban terhadap eksistensi PT MASA dengan memetakan faktor-faktor lingkungan internal dan eksternal perusahaan untuk merumuskan strategi bersaing yang dibutuhkan. Penelitian ini penting karena apabila perusahaan tidak menyusun strategi dengan baik, pada masa yang akan datang perusahaan akan kesulitan untuk mempertahankan bahkan mungkin dengan mudah kehilangan pelanggan atau pasarnya.

\section{LANDASAN TEORI}

\section{A. Perumusan Strategi}

Perumusan strategi dapat dilakukan melalui 3 langkah, yaitu formulasi strategi, implementasi strategi, dan evaluasi strategi [6]. Tahapan formulasi strategi dimulai dengan tahap input stage, yaitu tahap untuk memulai kuantifikasi proses perumusan strategi. Tahap ini juga menentukan faktor internal dan eksternal yang dianggap penting dalam menciptakan dan mengevaluasi strategi alternatif yang akan dirumuskan. Tools yang dapat digunakan dalam tahap input ini dalah Matriks EFE (Evaluasi Faktor Eksternal), Matriks EFI (Evaluasi Faktor Internal) dan Competitive Profile Matrix (CPM).

Lalu tahap selanjutnya adalah matching stage yaitu menyesuaikan faktor kekuatan dan kelemahan dengan peluang dan ancaman atau risiko yang dapat dihadapi. Penyesuaian faktor-faktor yang telah diidentifikasi tersebut secara efektif dapat mempermudah pihak perusahaan untuk merumuskan strategi alternatif. Tools yang dapatdigunakan pada tahap ini adalah Matriks SWOT (strengths, weaknesses, opportunities, threats), Matriks SPACE (Strategic Position and Action Evaluation), Matriks BCG (Boston Consulting Group), Matriks IE (Internal External), dan Matriks Grand Strategy.

Setelah melakukan penyesuaian, tahap terakhir adalah tahap pengambilan keputusan. Dalam tahap pengambilan keputusan ini, dibutuhkan intuisi dan analisis yang mendalam untuk mendapatkan strategi alternatif yang dibutuhkan. Strategistrategi alternatif yang sudah didapatkan sebelumnya akan diberikan kepada manajer atau karyawan yang berpartisipasi dalam melakukan analisis strategi dan aktivitas yang dipilih. Tools yang dapat digunakan pada tahap ini adalah Matriks Perencanaan Strategi Kuantitatif (QSPM).

\section{B. Analisis Industri}

Pada penelitian ini, dilakukan dua buah metode untuk melakukan analisis industri, yaitu Analisis PESTEL dan Porter's Five Forces. Menurut [7], analisis terhadap faktor lingkungan eksternal meliputi 4 bidang, yaitu politik, ekonomi, sosial dan teknologi. Analisis ini kemudian dikembangkan dengan penambahan aspek legal dan ekologi (lingkungan) sehingga dinamakan analisis PESTEL. Sementara itu, pada suatu industri terdapat lima kekuatan dalam persaingan industri yang dalam pembentukan strategi [4], yaitu ancaman pendatang baru, persaingan dengan perusahaan sejenis, daya tawar pemasok, daya tawar pembeli, dan ancaman produk substitusi.

\section{Business Model Canvas (BMC)}

Dalam perencanaan bisnis, perusahaan dapat membuat sebuah model bisnis untuk menggambarkan sistem bisnis yang akan dijalani. Sebuah bisnis model yang baik akan mampu menjelaskan bagaimana sebuah perusahaan atau organisasi dapat menciptakan, memberikan dan menangkap value yang diinginkan [5]. Terdapat 9 elemen pada bisnis model, yaitu Customer Segments, Value Propositions, Channels, Customer Relationships, Revenue Streams, Key Resources, Key Activities, Key Partnerships, dan Cost Structure.

\section{Matriks EFI dan Matriks EFE}

Tahap perumusan strategi dimulai dari tahap pencocokan dengan menggunakan Matriks Evaluasi Faktor Internal (EFI) dan Matriks Evaluasi Faktor Eksternal (EFE). Kedua matriks tersebut digunakan untuk melihat posisi perusahaan baik dari sisi internal maupun eksternalnya [6]. Jika perusahaan memiliki angka masing-masing 2,5 atau lebih untuk setiap matriks, dapat dikatakan bahwa para expert yang bekerja di perusahaan memahami keadaan internal dan eksternal perusahaan mereka [8].

\section{E. Matriks Portofolio Produk}

Dalam penelitian ini, matriks portofolio yang digunakan Matriks Internal-Eksternal (IE) sebagai portofolio perusahaan dan Matriks BCG sebagai portofolio produk. Matriks IE dilakukan untuk melihat posisi perusahaan baik dari sisi internal maupun eksternal, sedangkan Matriks BCG dilakukan untuk melihat pangsa pasar relatif dan pertumbuhan produk dari perusahaan [6]. 


\section{F. $Q S P M$}

Analisis QSPM adalah alat untuk melakukan pendekatan atau mengevaluasi strategi yang akan diterapkan sehingga dapat mengoptimalkan hasil yang diperoleh [9]. Pendekatan ini yang berfungsi untuk memilih strategi terbaik secara objektif menggunakan hasil input data dan faktor-faktor yang telah dimasukkan. Analisis ini menggunakan faktor internal dan faktor eksternal yang didapatkan pada input stage yaitu analisis internal-eksternal, dan mencocokkannya dengan hasil yang didapat dari matching stage yaitu matriks SWOT.

\section{METODE PENELITIAN}

Metode yang digunakan dalam penelitian ini adalah strategi formulasi yang terdiri dari tahap input, tahap pencocokan, dan tahap pengambilan keputusan [6]. Sebelumnya dilakukan analisis lingkungan eksternal dan internal terlebih dahulu untuk mengidentifikasi faktor SWOT dalam memudahkan perumusan strategi perusahaan [10]. digunakan tahap input yaitu Matriks EFE dan EFI.

Hasil dari tahap input digunakan untuk analisis pada tahap pencocokan dengan menggunakan matriks portofolio, yaitu Matriks IE dan Matriks BCG. Analisis portofolio akan dijadikan tema perumusan strategi alternatif pada pembuatan Matriks SWOT yang dapat memberikan gambaran mengenai peluang dan ancaman yang dihadapi perusahaan dan dapat disesuaikan dengan kekuatan serta kelemahan yang dimiliki oleh perusahaan tersebut [10].

Hasil perumusan strategi kemudian akan diperingkatkan dengan metode QSPM, dimana setiap strategi alternatif akan dibandingkan pengaruhnya dengan faktor internal dan eksternal yang telah diidentifikasi. Strategi-strategi alternatif yang memiliki Total Attractiveness Score tertinggi akan dijadikan bahan penyusunan rencana aksi bagi PT MASA untuk 5 tahun ke depan.

\section{HASIL DAN DISKUSI}

Berikut merupakan pengolahan data dan pembahasan analisis dari metode-metode yang digunakan.

\section{A. Analisis Industri}

Berdasarkan hasil analisis Porter's Five Forces yang terdapat pada Gambar 1, hambatan atau tantangan terbesar PT MASA dalam bersaing pada industri ban adalah persaingan dengan perusahaan sejenis. Hal ini disebabkan oleh para pesaing terberat PT MASA lebih dahulu berkecimpung pada industri ban dan menguasai pangsa pasar. Akibatnya, PT MASA sulit untuk mendapatkan pangsa pasar yang diinginkan mengingat tingginya brand loyalty.

\section{B. Analisis Bisnis Model}

Hasil analisis bisnis model akan memperlihatkan bahwa seluruh alur bisnis yang ada membutuhkan kapabilitas dari sisi operasional dan produksi perusahaan.

Dari penjabaran bisnis model pada Gambar 2, dapat dilihat bahwa PT MASA memiliki keunggulan dari sisi model tread yang unik dan berkualitas tinggi, serta memiliki range atau portofolio produk yang luas, baik dari ukuran rim maupun jumlah jenis ban yang diproduksi.

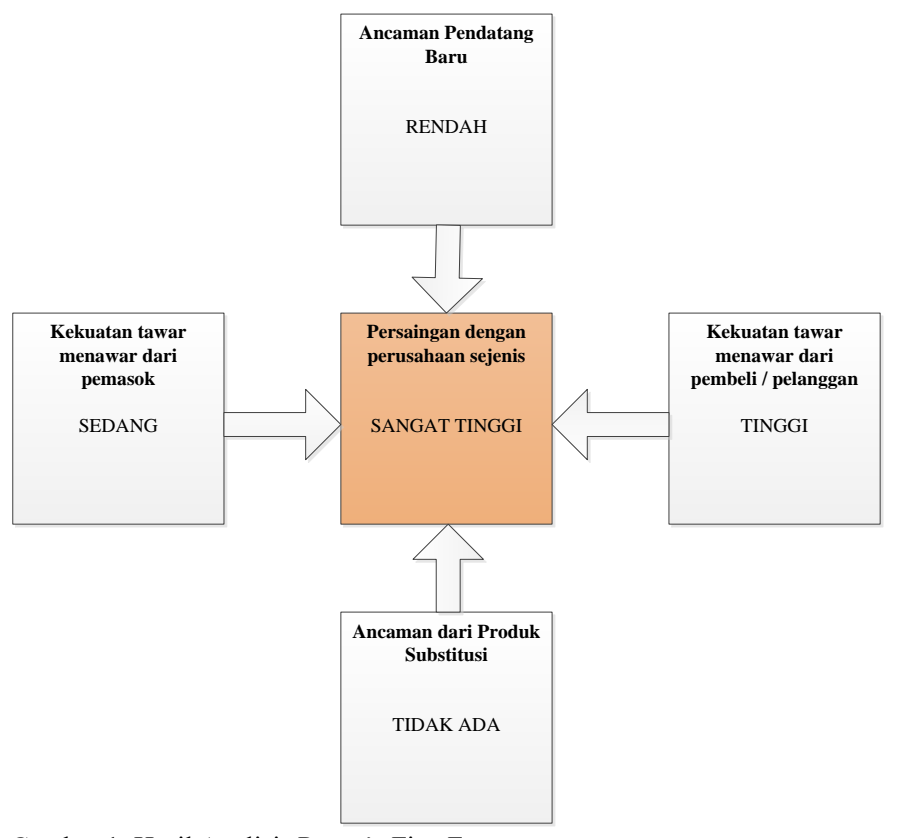

Gambar 1. Hasil Analisis Porter's Five Forces

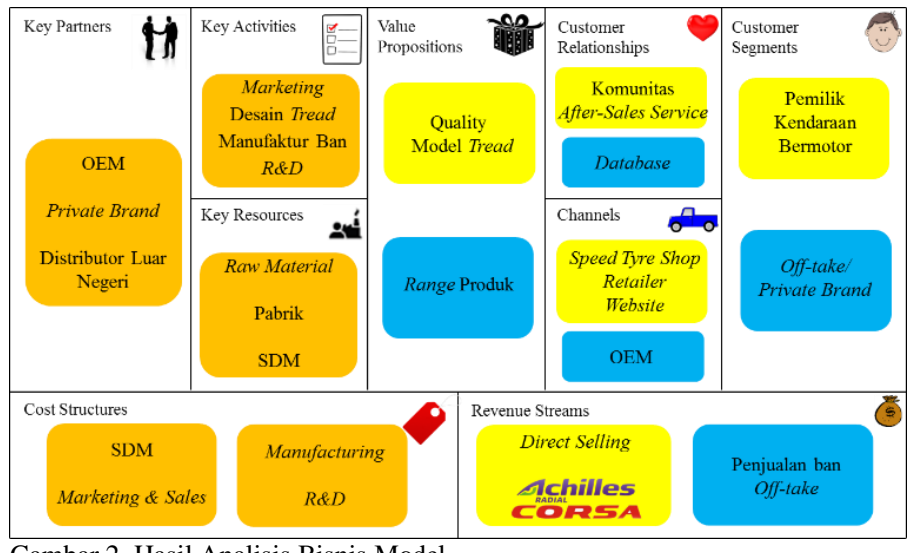

Berbagai keunggulan yang didapatkan dari bisnis model diatas tidak dapat dimaksimalkan oleh PT MASA karena PT MASA sendiri memiliki kelemahan yang besar, yaitu terbatasnya lahan produksi yang menyebabkan minimnya kapasitas produksi. Selain itu, sedikitnya outlet STS di daerahdaerah kecil membuat pihak pemasaran PT MASA kesulitan untuk menjangkau pasar di daerah tersebut. Hal tersebut menghambat PT MASA untuk menambah pangsa pasar dan menguasai industri ban di Indonesia.

\section{Tahap Input}

Setelah dilakukan analisis lingkungan internal dan eksternal, didapatkan masing-masing 8 kekuatan, 3 kelemahan, 8 peluang dan 7 ancaman yang akan digunakan untuk perumusan strategi pada penelitian ini. Dari hasil perhitungan nilai EFI dan EFE masing-masing 3,32 dan 3,26.

\section{Tahap Pencocokan}

Pada tahap pencocokan, diketahui bahwa nilai Matriks IE sesuai dengan Gambar 3 adalah $(3,32 ; 3,26)$. Hal itu menunjukkan bahwa PT MASA memiliki posisi internal yang 
kuat untuk mengembangkan kekuatan dan mengurangi kelemahannya. Sedangkan dari sisi eksternal, PT MASA dapat memaksimalkan peluang yang ada sambil mengantisipasi berbagai ancaman. Strategi yang direkomendasikan adalah grow and build.

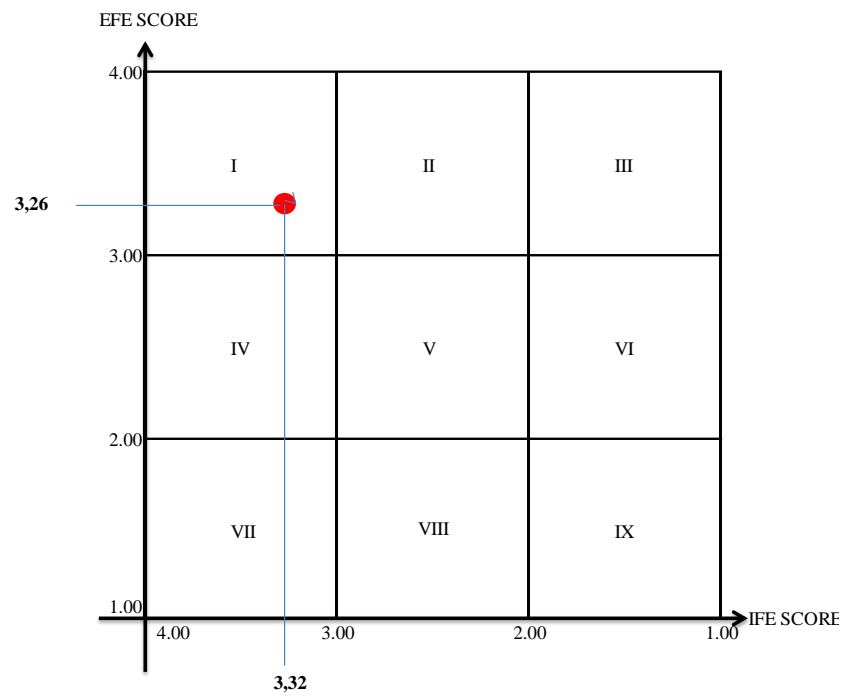

Gambar 3. Hasil Matriks IE

Pada Matriks BCG, didapatkan hasil sesuai pada Gambar 4 dan Gambar 5 bahwa Achilles berada pada kuadran dogs, sedangkan Corsa berada pada kuadran question marks. hal ini menunjukkan bahwa Achilles sebaiknya melakukan penghematan atau memaksimalkan penjualan ke daerah tertentu agar lebih profitable, sedangkan Corsa sebaiknya melakukan penetrasi pasar untuk menumbuhkan pangsa pasar.

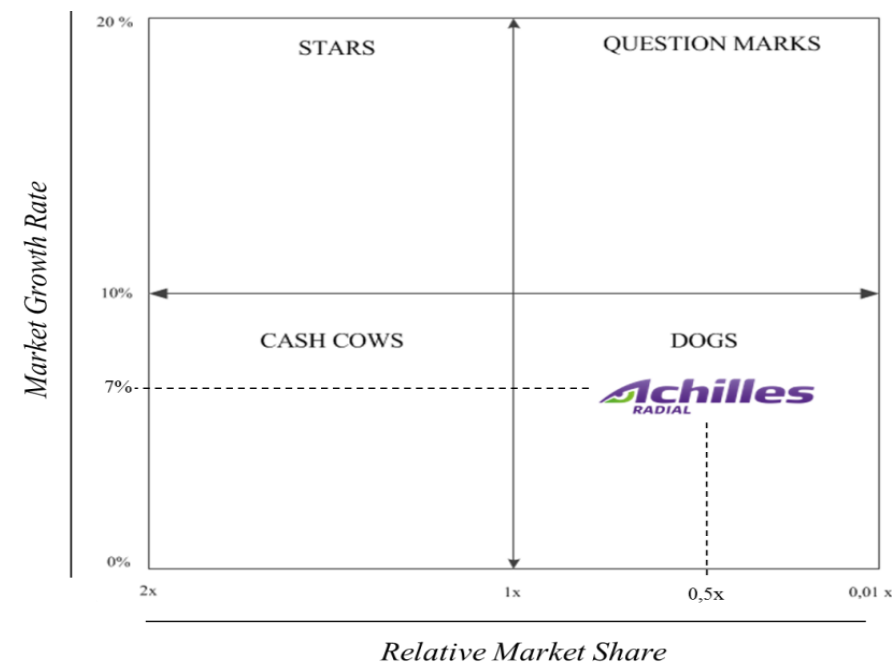

Gambar 3. Matriks BCG Ban Mobil Achilles

Perhitungan Matriks BCG untuk Achilles menggunakan penjualan ban mobil Bridgestone sebagai pembanding, sedangkan untuk Corsa digunakan penjualan ban motot Gajah Tunggal, Tbk. sebagai pembanding. Pembanding dipilih karena merupakan market leader dari masing-masing kategori produk.

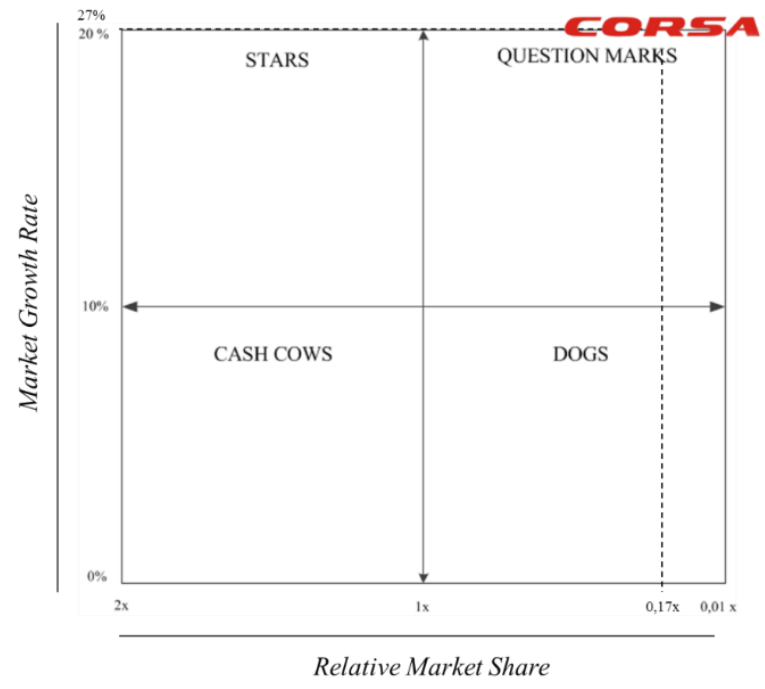

Gambar 5. Matriks BCG Ban Motor Corsa

\section{E. Tahap Pengambilan Keputusan}

Setelah dirumuskan strategi-strategi alternatif, dilakukan penghitungan TAS untuk mengetahui peringkat strategi-strategi alternatif yang akan diprioritaskan dalam penyusunan rencana aksi. Tabel 1 menunjukkan bahwa terdapat 7 strategi yang memiliki TAS tertinggi dan menjadi bahan penyusunan rencana aksi.

Tabel 1.

Urutan Peringkat Strategi Alternatif

\begin{tabular}{|c|c|c|}
\hline Peringkat & Strategi Alternatif & TAS \\
\hline 1 & $\begin{array}{l}\text { Menambah kerja sama dengan perusahaan } \\
\text { atau event perlombaan besar dunia }\end{array}$ & 7,362 \\
\hline 2 & Standarisasi bahan baku lokal dan impor & 7,011 \\
\hline 3 & $\begin{array}{l}\text { Memperbanyak kontrak dan kerjasama kepada } \\
\text { negara lain dalam melakukan distribusi } \\
\text { langsung produk ban }\end{array}$ & 6,909 \\
\hline 4 & $\begin{array}{l}\text { Membuka outlet Speed Tyre Shop di berbagai } \\
\text { daerah }\end{array}$ & 6,730 \\
\hline 5 & Menambah promosi via periklanan & 6,612 \\
\hline 6 & Mengadakan event otomotif di daerah pelosok & 6,525 \\
\hline 7 & $\begin{array}{l}\text { Melakukan ekspansi atau perluasan pabrik } \\
\text { untuk menambah kapasitas produksi }\end{array}$ & 6,359 \\
\hline 8 & $\begin{array}{l}\text { Mengembangkan jenis ban baru untuk } \\
\text { kendaraan berat }\end{array}$ & 5,971 \\
\hline 9 & Tidak melakukan penetrasi ke pelosok & 5,961 \\
\hline 10 & $\begin{array}{l}\text { Menambah persentase produksi ban untuk } \\
\text { kendaraan berat dari total kapasitas produksi }\end{array}$ & 5,943 \\
\hline 11 & $\begin{array}{l}\text { Menciptakan desain atau prototype ban untuk } \\
\text { pesawat }\end{array}$ & 5,791 \\
\hline 12 & Mengembangkan ban jenis agriculture & 5,531 \\
\hline 13 & $\begin{array}{l}\text { Memperluas lahan/menambah investasi pada } \\
\text { industri karet }\end{array}$ & 4,911 \\
\hline
\end{tabular}

\section{SIMPULAN DAN SARAN}

Berdasarkan pada hasil analisis dan diskusi yang telah dibahas, kesimpulan yang didapat adalah:

1. Industri ban saat ini belum stabil karena krisis ekonomi global yang menyebabkan penurunan penjualan dan permintaan domestik maupun ekspor. Hasil analisis Porter's Five Forces menunjukkan bahwa hambatan terbesar bagi PT MASA dalam berbisnis di industri ban adalah adanya persaingan dengan perusahaan sejenis karena para pesaing PT MASA 
adalah penguasa pangsa pasar dan sudah memiliki brand loyalty yang tinggi.

2. Terdapat delapan kekuatan dan empat kelemahan dari hasil analisis lingkungan internal menggunakan pembuatan bisnis model. PT MASA memiliki keunggulan dari sisi model tread yang unik dan berkualitas tinggi, serta memiliki range atau portofolio produk yang luas. Berbagai keunggulan yang didapatkan dari bisnis model diatas tidak dapat dimaksimalkan oleh PT MASA karena PT MASA sendiri memiliki kelemahan yang besar, yaitu kapasitas produksi yang minim. Sementara itu, terdapat delapan peluang dan tujuh ancaman dari hasil analisis lingkungan eksternal yang telah diidentifikasi. Amerika sebagai pasar potensial merupakan peluang bagi PT MASA untuk memaksimalkan penjualannya, namun adanya krisis ekonomi global menyebabkan fluktuasi mata uang asing yang berpengaruh besar terhadap penjualan PT MASA.

3. Berdasarkan pada hasil pemetaan Matriks Internal-Eksternal (Matriks IE), PT MASA memiliki nilai Evaluasi Faktor Internal (EFI) sebesar 3,32; Lalu nilai Evaluasi Faktor Eksternal (EFE) yang didapatkan adalah 3,26. PT MASA berada pada kuadran I yang berarti kedudukan PT MASA pada industri dapat dikatakan kuat dan berpotensi besar untuk mempertahankan posisi dan berusaha untuk melakukan pengembangan perusahaan dengan melakukan strategi intensif (penetrasi pasar, pengembangan pasar, dan pengembangan produk). Sementara itu, pada pemetaan Matriks BCG menunjukkan bahwa produk ban mobil Achilles sedang berada pada kuadran dogs. Perumusan strategi bersaing menghasilkan 13 strategi yang didapat dari pembuatan Matriks SWOT. Terdapat 3 strategi alternatif yang mendapat TAS tertinggi, yaitu menambah kerja sama dengan perusahaan atau event perlombaan besar dunia, standarisasi bahan baku lokal dan impor, dan memperbanyak kontrak atau kerjasama dengan negara lain dalam melakukan distribusi langsung produk ban. Pelaksanaan rencana aksi dalam lima tahun kedepan dilaksanakan kepada 7 strategi alternatif yang memiliki TAS tertinggi melalui penghitungan metode QSPM.

Saran yang dapat diberikan untuk PT MASA dan bagi penelitian selanjutnya adalah:

1.Penelitian ini hanya melakukan tahap perumusan dan implementasi terhadap strategi alternatif yang telah diidentifikasi. Penelitian selanjutnya dapat membahas tentang evaluasi mengenai strategi alternatif yang telah direkomendasikan.

2. Setiap strategi alternatif yang telah dirumuskan mempunyai skala prioritas yang dapat berubah setiap waktunya. Hal ini dapat disesuaikan dengan kebutuhan PT MASA serta kondisi pasar industri ban pada periode tertentu. Peningkatan kinerja terutama dari sisi produksi dan operasional sangat dibutuhkan untuk memaksimalkan utilisasi produk.

3. Penelitian selanjutnya dapat melakukan pembaharuan terhadap bisnis model yang sudah ada. Pengembangan bisnis model yang baru dapat dilakukan dengan menggunakan analisis SWOT terhadap masing-masing elemen yang ada pada bisnis model. Pembaharuan dapat dilakukan sesuai dengan kondisi dan kebutuhan dari perusahaan.

\section{DAFTAR PUSTAKA}

[1] Asosiasi Perusahaan Ban Indonesia (2013). Laporan APBI Tahun 2013. Jakarta: APBI

[2] PT Multistrada Arah Sarana. (2014). Annual report: Going Forward through Quality \& People Performance. Jakarta: PT Multistrada Arah Sarana.

[3] Johnson, K. \& Kevan, S.. (2005). Exploring Corporate Strategy $7^{\text {th }}$ edition. New Jersey: Prentice-Hall International.

[4] Porter, M. E. (2008). Competitive Strategy Techniques for Analyzing Industries and Competitors. New York: The Free Press.

[5] Osterwalder, A. \& Yves P. (2010). Business Model Generation. New Jersey: John Wiley \& Sons, Inc.

[6] David, F. (2011). Strategic Management $13^{\text {th }}$ edition. New Jersey: Prentice Hall..

[7] Ward, J. \& Joe P.. (2002). Strategic Planning for Information System $13^{\text {rd }}$ Edition. New York: John Wiley and Sons, Inc.

[8] Homayoun, A., Mohsen, S., Vatandoost, R., \& Dastani, R. (2015). Strategy planning for joint-stock companies, Case study: software development and production in DIDGAH RAYANEH SAMA. Procedia - Social and Behavioral Sciences, 181, 303-312.

[9] Zulkarnaen, H. O. \& Sutopo. (2013). Analisis Strategi Pemasaran Pada Usaha Kecil Menengah (UKM) Makanan Ringan (Studi Penelitian UKM Snack Barokah di Solo). Diponegoro Journal of Management. 2, 1-13.

[10] Rangkuti, F. (2006). Analisis SWOT: Teknik Membedah Kasus Bisnis. Jakarta: Gramedia Pustaka Utama. 